\title{
Simplified deformation models of the plain milling cutter subjected to cutting forces loads when milling the aluminum alloy Al 7075
}

\author{
Uproszczone modele deformacji frezu walcowego \\ poddanego obciążeniom pochodzącym od sił skrawania \\ podczas frezowania stopu aluminium Al 7075
}

\author{
ANDRZEJ KAWALEC \\ KONRAD SZAŁĘGA *
}

DOI: https://doi.org/10.17814/mechanik.2017.11.154
The problem of geometric modeling of the plain milling cutter and its deflection under the influence of loads mapping forces occurring during the milling of the Al 7075 alloy surface is discussed. In modeling, 2 types of plain milling cutters are included: with rectilinear cutting edges and with helical cutting edges. The influence of concentrated forces and different distributions of loads mapping the cutting forces, is considered. Conclusions are drawn regarding the influence of the force inclination angles relative to the selected axis of the coordinate system on the generated effective stresses and cutter deformations. The finite element method was used to calculate the displacements, deformations and stresses.

KEYWORDS: milling, plain milling cutter, finite element method, displacements, strains, stresses

In aviation technology, besides functionality of the product, its high strength, low weight, safety of use and environmental friendliness all play a very important role. This results in the increasingly widespread use of monolithic structures, often thin-walled, milled, and made of light metal alloys or composites [1]. One of such materials is the Al 7075 aluminum alloy, designated as Al-5,6Zn-2,5Mg-1,6Cu-0,23Cr with a density of 2.81 $\mathrm{g} / \mathrm{cm}^{3}$, Young's modulus of $72 \mathrm{GPa}$, and tensile strength in the T6 state, i.e. after over-saturation and artificial aging, of $350 \mathrm{MPa}$ [1]. Although - like other $\mathrm{Al}-\mathrm{Zn}-\mathrm{Mg}-\mathrm{Cu}$ alloys - it is also susceptible to cracking due to stress corrosion, but because of its relatively high strength, the Al 7075 alloy is widely used in aviation [1].

The most important factors influencing the accuracy of the shape and dimensions of the product reached on the CNC machine are: kinematics, dynamics, rigidity and accuracy of the machine tool and the CNC control system. There are also important: temperature distribution in the working area, loads present during machining, rigidity of the tools and their wear, attachment of the workpiece and properties of the materials composing a workpiece and a tool [1, 2]. Milling of

\footnotetext{
*Dr hab. inż. Andrzej Kawalec prof. PRz (ak@prz.edu.pl) Katedra Technik Wytwarzania i Automatyzacji, Wydział Budowy Maszyn i Lotnictwa Politechniki Rzeszowskiej; inż. Konrad Szałęga (konrad.szalega@o2.pl) - Wydział Budowy Maszyn i Lotnictwa Politechniki Rzeszowskiej
}

aluminum alloys is not as large a problem as milling the alloys based on titanium or nickel. However, when milling large cavities of a material - which is common in cavity molding of lightweight monolithic structures - especially in aviation, it is necessary to use a cutter with a significant overhang.

Cutting forces cause a complex state of stress the in a cutter, which is the result of bending, torsion, compression and shear. This, in turn, leads to deformation of the cutter, which may result in an excessive errors of the workpiece being produced. The cross-section of the cut layer is also altered. The interaction of these factors in the elastic and elasticplastic ranges is associated with a change in the load over time, which leads to vibrations, which translates to the errors of the shape and dimensions of the product. Minimizing these errors requires performing the study and numerical experiments to determine the displacement, deformations and stresses in shaped products, tools, and devices.

Experimental study upon the phenomena occurring during cutting is difficult and often subjected to large measuring errors. The cause is, among others, the lack of appropriate measurement methods and systems. Numerical analysis can roughly predict the impact of selected parameters - describing, for instance, their material properties, technological process conditions, resulting heat - on the field of deformations, stresses, temperatures, accuracy of the final product, quality of the shaped surface, etc. [1-9].

\section{Purpose and scope of research}

The aim of the study was to make simplified, spatial models of plain milling cutter that affects the workpiece as well as to calculate the deformation of the cutter and resulting reduced stresses.

\section{Methodology of research}

The finite element method (FEM) was used for strength calculations. Both geometrical modeling and deformation mechanics calculations were performed applying the CAD/CAM/CAE NX 9.0 system [10]. 


\section{Developed models and conditions for calculations}

By using a uniform CAD/CAM/CAE environment, geometric transformation errors have been avoided, which typically result from the export of geometric data from the CAD system into the universal formats, e.g. frequently used IGES and STEP, and with respect to the core of geometry NX 9.0 system - also Parasolid $®$ format. Importing these data into the FEM calculation system results in subsequent errors of the original model mapping.

The basis for the models used for the strength calculations were spatial geometrical CAD models of the plain milling cutter. They represented a plain milling cutter with straight and helical cutting edges and grooves (fig. 1 and fig. 2). The cutter geometry modeling was based on the CoroMill Plura plain milling cutter designated as R216.35-14045-AC26N [11]. a)

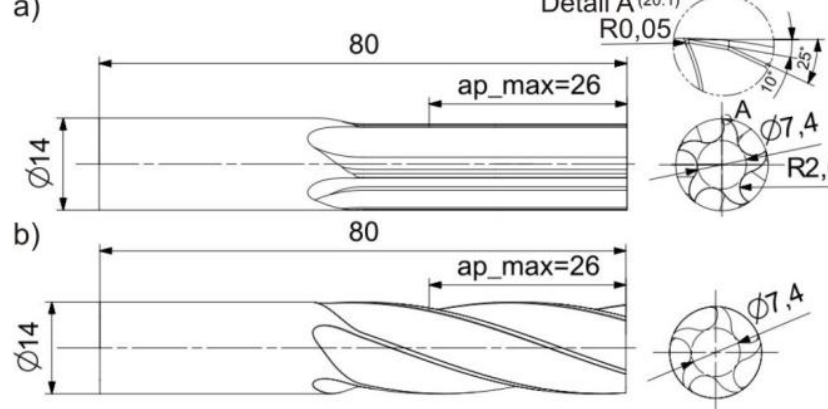

Fig. 1. Basic geometrical dimensions of CAD models of plain milling cutters with: a) rectilinear and b) helical cutting edges (helix angle $20^{\circ}$ ); ap_max - the maximum cutting depth $a_{p}$
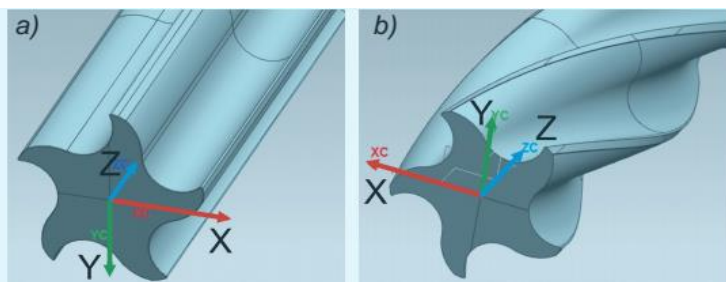

Fig. 2. CAD models of plain milling cutter with: a) rectilinear, b) helical cutting edges

Twenty FEM models of cutters differing in shape, the FE mesh or applied load, were made. Due to the need to map the force distributions along the cutting edge of the milling cutter, each of the surface of the milling cutter grooves and the surfaces and curves forming the cutting edges were divided by a plane perpendicular to the milling cutter axis into 2 components (fig. 2).

It was assumed that the cutter is mounted in a rigid holder. It was modeled by taking all degrees of freedom in the plane of cross-section corresponding to the boundary surface of the cutter holder. The resulting loads were calculated roughly for the case of milling with the side surface of the monolithic cutter with a diameter of $D$ $=14 \mathrm{~mm}$, cutting depth $a_{p}=20 \mathrm{~mm}$, cutting width $a_{e}=$ $2 \mathrm{~mm}$, cutting speed $v_{c}=650 \mathrm{~m} / \mathrm{min}$ and blade feedrate $f_{z}=0.03 \mathrm{~mm}$, taking 5 cutting edges with an inclination of $0^{\circ}$ or $20^{\circ}$, respectively for a milling cutter with straight and helical cutting edges [12].

It has been assumed that the product wall made of $\mathrm{Al}$ 7075 alloy machined by means of milling, as well as the tool holder, are both rigid. The impact of the vulnerability of the wall on deformations caused by the cutting forces was examined in other publications, including [8].
Calculations used FEM with linear finite elements in the shape of a pyramid. The FE grid has been compacted in the vicinity of the cutting edges. The curvature radius of the cutting edges was comparable to the tolerance of curve modeling in CAD system, i.e. $0.005 \mathrm{~mm}$. Calculations were also performed for a radius of $0.05 \mathrm{~mm}$. It was assumed that the monolithic tools are made of high speed steel ASTM M10. For both cutters, a flexible, isotropic model of material with the Young's modulus $E=207 \mathrm{GPa}$ and Poisson's ratio $v=0.3$ were adopted $[1,3]$.

The cutter load model presented in [9] assumes the load originating only from the concentrated force applied in the milling cutter axis or from the concentrated forces applied at the selected points to the cutter cutting edges. In this paper, the load is defined as either a concentrated force applied at the end of the tool axis or continuous force distributions along the cutting edges, which obviously better reproduces the milling conditions.

Several cases of load orientation in space were considered. The first of them only served for rough estimation of the cutter rigidity by calculating the maximum displacement caused by the concentrated force. The second, much better reproducing the actual interaction of the cutter with the workpiece, included the forces distributed along the cutting edges being in a temporary contact with the workpiece, inclined at different angles $\omega_{i} \in\left\{0^{\circ}, 30^{\circ}, 45^{\circ}, 60^{\circ}, 90^{\circ}\right\}$ relative to the selected $X$ axis of the reference system (fig. 3 ).
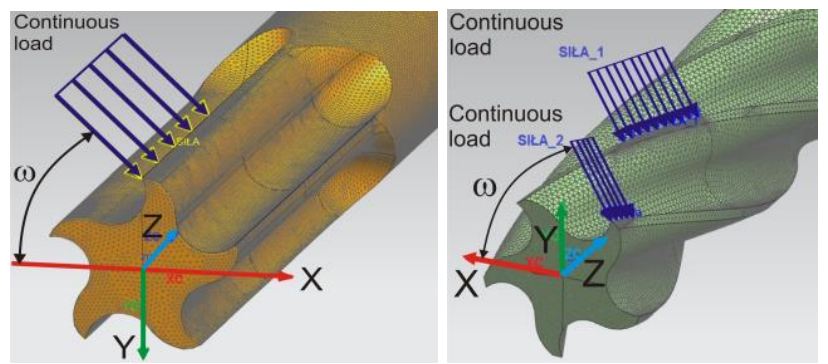

Fig. 3. Load in FEM cutter models with continuous cutting forces distributed along: a) rectilinear $b$ ) helical cutting edges

It was assumed the spatial orientation of the cutting forces can vary as a result of vibrations caused by a periodic contact of the cutting edges with the workpiece. Taking that into account, the variability of the angle $\omega_{i}$ in the range $\left\langle 0^{\circ}, 90^{\circ}\right\rangle$ is due to the need to reveal the general tendency of bending and reduced Huber-MisesHencky $(\mathrm{HMH})$ stresses [1] in the tool in a range including 2 mutually orthogonal directions. At the same time, a simplifying assumption was adopted that the average value of the resultant cutting force remains constant at $395 \mathrm{~N}$ resulting from the preliminary calculations.

In the case of a milling cutter with helical cutting edges, two load variants were adopted - with 1 or 2 edges being in a temporary contact with the workpiece. In the latter case, the force component per edge in contact with the workpiece was calculated with the involvement of the edge length share in the total length of the cutting edges of the cutter being in a momentary contact with the workpiece (fig. 3b).

\section{Results}

The results of FEM calculations in the form of maximum cutter displacements $\delta_{\max }$ and maximum reduced $\mathrm{HMH}$ stresses $\sigma_{H M H, \max }$ are shown in fig. 4 and 
fig. 5 , respectively. The displacements $\delta_{\max }$ caused by the concentrated cutting force applied in the milling cutter axis with rectilinear and helical cutting edges are respectively $0.244 \mathrm{~mm}$ and $0.254 \mathrm{~mm}$.

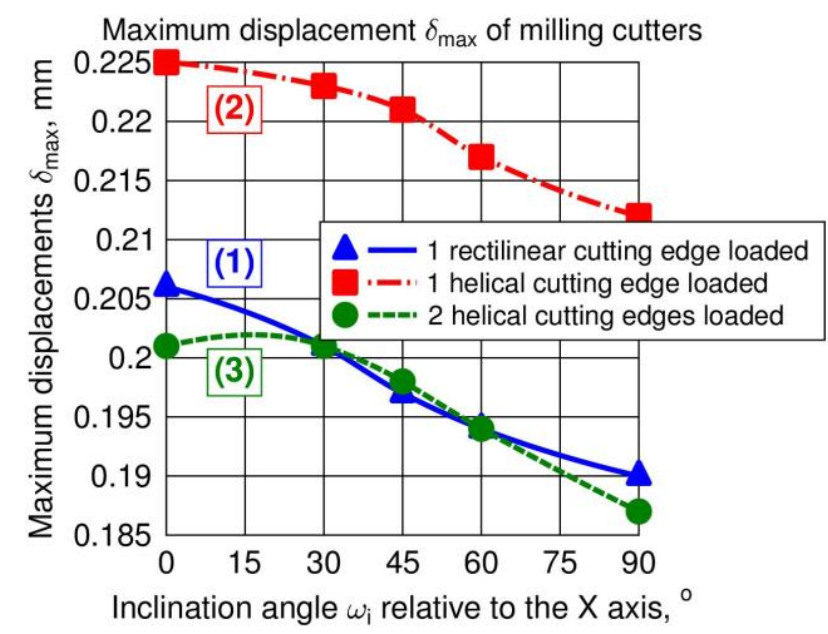

Fig. 4. Maximum displacement $\delta_{\max }$ of milling cutters with rectilinear and helical cutting edges depending on the inclination angle $\omega_{i}$ relative to the $X$ axis of load originating from the cutting forces continuously distributed along 1 or 2 cutting edges

The regression equations $\delta_{\text {max, } i(\omega)}$ of the maximum deflections (curves $(1) \div(3)$ in fig. 4 ) of deformed milling cutters are of the form:

$$
\begin{aligned}
& \delta_{\max , 1}=0,206-2,17 \mathrm{e}-4^{\star} \omega+3,70 \mathrm{e}-7^{\star} \omega^{2} \\
& \delta_{\max , 2}=0,225-5,95 \mathrm{e}-5^{\star} \omega-1,01 \mathrm{e}-6^{\star} \omega^{2} \\
& \delta_{\max , 3}=0,201+1,29 \mathrm{e}-5^{\star} \omega-1,96 \mathrm{e}-6^{\star} \omega^{2}
\end{aligned}
$$

Determination coefficients of the regression models $(1) \div(3)$ are respectively: $0.99,0.99$ and 0.98 .

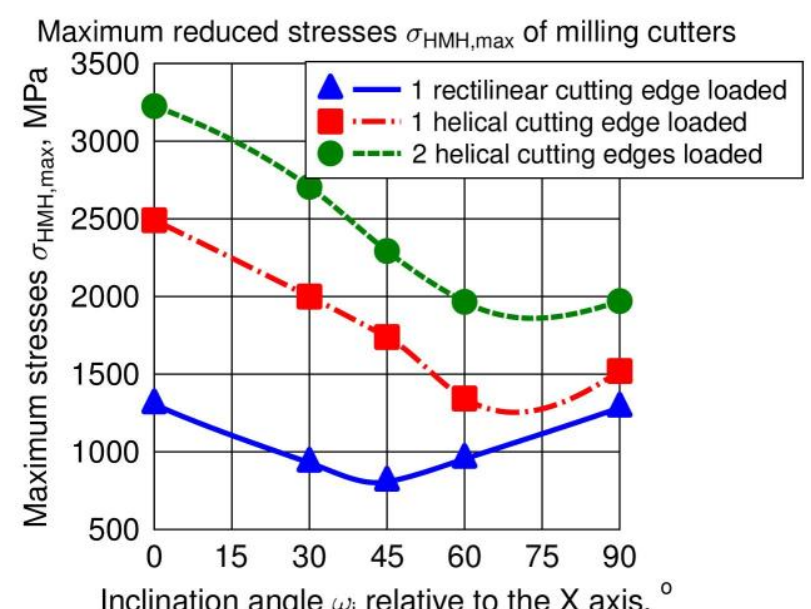

Fig. 5. Maximum stresses $\delta_{\text {HMH.max }}$ of milling cutters with rectilinear and helical cutting edges depending on the inclination angle $\omega_{i}$ relative to the $X$ axis of load originating from the cutting forces continuously distributed along 1 or 2 cutting edges

With the increase of the angle $\omega_{i}$, the maximum displacement of the cutter $\delta_{\max }$ decreases (fig. 4). Model with the cutting force applied in the cutter axis leads to $\delta_{\max }$ values comparable to $\delta_{\max }$ in models with a continuous load applied to the cutting edges. Milling cutter models with continuous load distributions along the cutting edges are, of course, closer to the actual operating conditions. Stress change $\sigma_{H M H, \max }$ in the rectilinear edge milling cutter is symmetrical to the angle $\omega_{i}=45^{\circ}$, for which $\sigma_{H M H, \text { max }}$ values are the smallest. The stresses $\sigma_{H M H, \max }$ in the helical cutting edge milling cutters decrease with $\omega_{i}$ angle increase from $0^{\circ}$ to $60^{\circ}$, and then they are stabilized within a specified range of stresses. Large displacement values $\delta_{\max }$ may result from the application of the load to the edge of the surface. Calculated $\delta_{\max }$ for cutters with rectilinear cutting edges with a curvature radius of $0.05 \mathrm{~mm}$, loaded with forces distributed along the sections corresponding to the cutting depth $a_{p}$, differ from those in fig. 4 by less than $10 \%$. It can be associated with the application of continuous load to the edge of the surface representing the cutting edge of the milling cutter.

\section{Conclusions}

The developed FEM models of cutters are characterized by a high degree of simplicity. They do not include effect of temperature and high deformation rate. More complex constitutive models, such as the JohnsonCook model [1, 3, 6, 7], require more advanced FEM program, wider computing range, and much more powerful computer than the one available. The FEM models of cutters developed in the paper emphasize the accurate representation of the shape of these tools and various forms of loads originating from the cutting forces and acting on them. They must be developed in the future, taking into account the characteristics of material properties, that have been simplified or omitted here.

In spite of these simplifications, the developed models can serve to approximate the deformation of the milling cutter and the stresses generated in it - under the influence of applied loads. This information can also be helpful in predicting the scale of the workpiece errors.

The displacement fields and their maximum values vary depending on the method of the cutter loading, e.g. its orientation. The maximum displacement $\delta_{\max }$ in the rectilinear edge cutter model with the concentrated force applied at the end of its axis is $16 \div 22 \%$ greater than that of the exact geometric model, depending on the load direction. In the case of helical cutting edges, this difference is from $11 \%$ to $26 \%$, which is affected by the direction of the forces and the number of cutting edges loaded.

\section{REFERENCES}

1. Oczoś K.E., Kawalec A. „Kształtowanie metali lekkich”. PWN, Warszawa 2012.

2. Kawalec A., Magdziak M. "Deformations of selected milling cutters while milling Ti6Al4V alloy on a CNC machine tool, experimental tests and FEM modeling". Advances in Manufacturing Science and Technology. 35, 4 (2011): pp. 19-31.

3. Grzesik W. "Advanced Machining Processes of Metallic Materials: Theory, Modelling, and Applications". 2nd ed. Elsevier, 2017.

4. Zębala W. „Modelowanie procesu skrawania”. Kraków: Wydawnictwo Politechniki Krakowskiej, 2011.

5. Niesłony P., Grzesik W., Chudy R. „Wpływ dyskretyzacji modelu narzędzia na efekt symulacji MES procesu skrawania". Mechanik. 87, 8-9 (2013): pp. 89-96.

6. Niesłony P., Grzesik W. „Modelowanie procesu i operacji skrawania metodą elementów skończonych 
(MES). Part I. Podstawy i programy symulacyjne". Mechanik. 86, 10 (2013): pp. 825-832.

7. Niesłony P., Grzesik W. „Modelowanie procesu i operacji skrawania z zastosowaniem metody elementów skończonych (MES). Part II. Przykłady zastosowań praktycznych". Mechanik. 86, 11 (2013): pp. 909-917.

8. Kawalec A., Płodzień M. „Uproszczony dwuwymiarowy model ugięć cienkiej ścianki wywołanych siłą odporową od frezu". Mechanik. 89, 10 (2016): pp. 1524-1525.

9. Burek J., Żyłka Ł., Płodzień M., Szajna A. „Analiza sztywności frezu trzpieniowego". Mechanik. 89, 10 (2016): pp. 1520-1521.

10. Siemens PLM Software. „PLM-Product Lifetime Management". Url: www.plm.automation.siemens.com/pl_pl (access: 21.11.2016)

11. Sandvik Coromant. „Narzędzia obrotowe”. Warszawa 2009.

12. ISCAR cutting parameters calculator. Url: mpwr.iscar.com/machiningpwr (dostęp: 25.11.2016).

13. MatWeb. Material property data. Url: www.matweb.com (access: 25.11.2016). 